\title{
A Nonsense Mutation in the Erythrocyte Band 3 Gene Associated with Decreased mRNA Accumulation in a Kindred with Dominant Hereditary Spherocytosis
}

\author{
Patricia B. Jenkins, Ghassan K. Abou-Alfa, Didier Dhermy, ${ }^{\ddagger}$ Elizabeth Bursaux, ${ }^{\S}$ Claude Féo, ${ }^{\S \dagger}$ Alphonse L. Scarpa, \\ Samuel E. Lux, Michel Garbarz, ${ }^{\ddagger}$ Bernard G. Forget, and Patrick G. Gallagher* \\ Departments of Internal Medicine, Genetics, and *Pediatrics, Yale University School of Medicine, New Haven, Connecticut 06520;

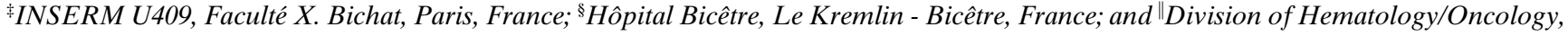 \\ Children's Hospital, Harvard Medical School, Boston, Massachusetts 02138
}

\begin{abstract}
We studied a French kindred with typical hereditary spherocytosis (HS). Studies of erythrocytes and erythrocyte membranes from HS individuals revealed abnormal erythrocyte membrane mechanical stability as well as a $15-20 \%$ deficiency of band 3, the anion transporter. Anion transport studies of red cells from two affected individuals revealed decreased sulfate flux. Nucleotide sequence of cDNA encoding the distal third of the cytoplasmic domain and the entire transmembrane domain of band 3 obtained by RT-PCR of reticulocyte RNA of an affected family member was normal. Sequence analysis of genomic DNA from an HS individual identified a nonsense mutation of the band 3 gene, Q330X, near the end of the band 3 cytoplasmic domain. This mutation was present in genomic DNA of all HS family members and absent in DNA of unaffected family members. Using an RT-PCR-based assay, a marked quantitative decrease in accumulation of the mutant band 3 RNA was detected. Thus the codon 330 nonsense mutation is responsible for the decreased accumulation of mutant band 3 RNA and the deficiency of band 3 protein in this kindred. These results have important implications for the role of band 3 defects in the membrane pathobiology of HS as well as for the techniques used in detection of HS mutations. (J. Clin. Invest. 1996. 97:373-380.) Key words: DNA sequence • polymerase chain reaction $\cdot$ hemolytic anemia $\cdot$ membrane protein $\bullet$ anion exchange
\end{abstract}

\section{Introduction}

Hereditary spherocytosis (HS) ${ }^{1}$ is a congenital hemolytic anemia characterized by spherocytic RBCs which have increased

\footnotetext{
${ }^{\dagger}$ Deceased.

Portions of this work have been published in abstract form (1992. Blood. 80[Suppl. 1]:145a and 1994. Blood. 84[Suppl. 1]:6a).

Address correspondence to B. G. Forget, M.D., Hematology Section, Department of Internal Medicine, Yale University School of Medicine, 333 Cedar St., P.O. Box 208021, New Haven, CT 065208021. Phone: 203-785-4144; FAX: 203-785-7232.

Received for publication 3 January 1995 and accepted in revised form 12 October 1995.
}

1. Abbreviations used in this paper: DIDS, di-isothiocyano-dihydrostilbene-disulfonate; EI, ektacytometric index; HS, hereditary spherocytosis.

J. Clin. Invest.

(C) The American Society for Clinical Investigation

0021-9738/96/01/373/08 \$2.00

Volume 97, Number 2, January 1996, 373-380 osmotic and mechanical fragility (1-4). The principal cellular lesion is loss of membrane surface area relative to intracellular volume which accounts for the spheroidal shape and decreased deformability of the red cell. HS is clinically, genetically, and biochemically heterogeneous. Typically, HS is inherited in an autosomal dominant manner and has a variable clinical phenotype (1-4). HS has been associated with quantitative and/or qualitative abnormalities of several different erythrocyte membrane proteins including spectrin, ankyrin, band 3 , and protein 4.2 (1-4, and references therein).

Band 3, the anion exchanger (AE1, EPB3), is the major transmembrane protein of the erythrocyte, comprising $\sim 25 \%$ of total red cell membrane protein (5). It is a glycoprotein that appears as a diffuse band of $90-100 \mathrm{kD}$ when analyzed by SDS-PAGE. It is composed of two distinct domains, an $\sim 40$ $\mathrm{kD}$ cytoplasmic domain and an $\sim 55 \mathrm{kD}$ membrane-spanning domain. The $\mathrm{NH}_{2}$-terminal cytoplasmic domain binds several glycolytic enzymes and mediates interactions between band 3 and the membrane skeleton via ankyrin, protein 4.1, and protein 4.2. The $\mathrm{COOH}$-terminal membrane-spanning domain is thought to transverse the membrane $\sim 14$ times and is responsible for anion exchange across the membrane (5).

There is a subset of patients with typical, dominantly inherited HS whose red cells are deficient in band 3 (6-11). Genetic defects have been reported (mostly in the form of abstracts) in a number of these cases, and they include frameshift, nonsense, and splicing mutations as well as missense mutations in the cytoplasmic and transmembrane domains of the protein (12-15). However, the precise basis of band 3 deficiency in many of these patients is unclear. Furthermore, it is not clear by what mechanisms band 3 deficiency alone (in the absence of a structurally abnormal band 3 protein) can lead to HS.

This report describes a French kindred with typical dominantly inherited hereditary spherocytosis associated with band 3 deficiency and abnormal erythrocyte anion transport. Analysis of DNA polymorphisms excluded linkage of HS to the genes encoding $\alpha$-spectrin, $\beta$-spectrin, ankyrin, and protein 4.1, but did not exclude linkage of HS to the band 3 gene. The nucleotide sequence of cDNAs encoding the distal one-third of the cytoplasmic domain and the entire transmembrane domain of band 3 obtained by RT-PCR of reticulocyte RNA of an affected family member was normal. Sequence analysis of genomic DNA from the same HS individual revealed a nucleotide substitution, CAG to TAG, Q330X, near the end of the cytoplasmic domain of the protein, that was not detected in the corresponding reticulocyte cDNA of the individual. This nonsense mutation was present only in the affected HS individuals of this family. Using an RT-PCR-based assay, a marked quantitative decrease in accumulation of the mutant band 3 mRNA was observed. These results indicate that the codon 330 nonsense mutation is responsible for the markedly decreased accu- 


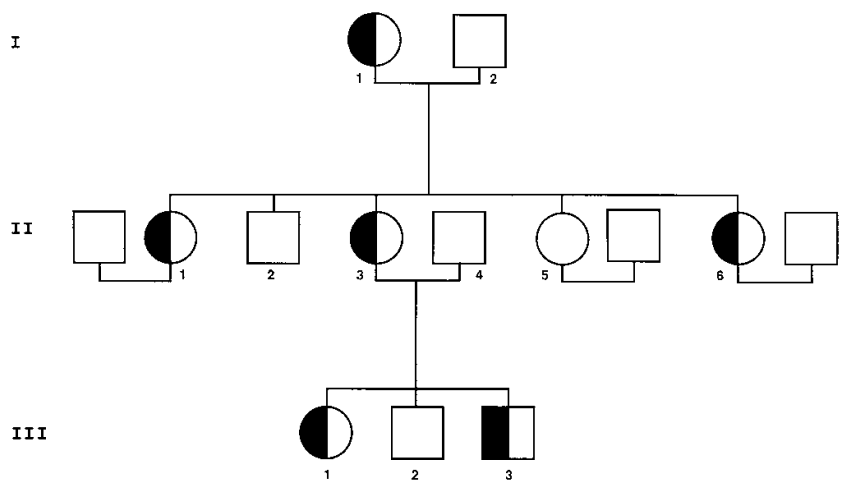

Figure 1. Pedigree of the family showing a dominant pattern of inheritance of HS. Affected HS individuals are designated by the halffilled symbols.

mulation of mutant band 3 mRNA and the deficiency of band 3 associated with HS in this kindred. We have named this variant band 3 Noirterre, after the village of residence of the family in France.

\section{Methods}

Case report. We studied a three-generation Caucasian family from Noirterre, France. HS was first diagnosed in the proband $\left(\mathrm{II}_{3}\right)$ (Fig. 1) who manifested compensated hemolytic anemia and splenomegaly. Studies of family members led to the diagnosis of dominantly inherited HS in six individuals (Table I). Spherocytes were present in the peripheral blood smears of all affected family members; a few "pincer" cells were also seen in the smears of patients $\mathrm{I}_{1}$ and $\mathrm{III}_{1}$. Affected subjects suffered from varying degrees of anemia with hemoglobin levels ranging between 10 and 15 grams/dl; reticulocyte counts ranged between 2.6 and $9 \%$ (Table I). There was variable splenomegaly. None of the affected individuals had undergone splenectomy. Other family members were hematologically normal.

Mechanical stability of erythrocyte membranes. These studies were performed using an ektacytometer. Whole red cell deformability was followed as a function of the osmolality of the suspending medium, as previously described (16). The membrane resistance to shear-induced fragmentation was also measured, as described (17).
Table II. Oligonucleotide Primers

\begin{tabular}{ll}
\hline Primer & \multicolumn{1}{c}{ Sequence } \\
\hline A & 5'-CATCTGGAATTCTGGAAAAGATTCCCCCG-3' \\
B & 5'-CGGAATTCGCTGCTGCACTCCCTAGA-3' \\
C & 5'-GCGGAATCCTGCCCAACACAGCCCTCC-3' \\
D & 5'-GCGCTGCAGCCCAGATCCAGGAGG-3' \\
E & 5'-GGACCTGGGGGCTGAATGCATC-3' \\
F & 5'-GGAAGCTTGAAGGTACCGGCCATGAGC-3' \\
G & 5'-CGCGAATTCCATGAGGATGGACAGGCC-3' \\
H & 5'-CGAAGCTTCTGCTTTTCCTTGGAAGGTGG-3'
\end{tabular}

The locations of oligonuclotide primers in the band $3 \mathrm{cDNA}$ are shown in Fig. 2.

Preparation and analysis of erythrocyte membranes. Erythrocyte membranes were prepared from peripheral blood as described (18) and separated in $3.5-15 \%$ gradient polyacrylamide gels by SDSPAGE as described (19). Spectrin/band 3 ratios were obtained by scanning the gels. Membranes were depleted of integral proteins, converted into inside-out vesicles, and treated with chymotrypsin, and the $41-43-\mathrm{kD}$ cytoplasmic domain of band 3 was isolated by DE52 cellulose column chromatography (20). This fragment was then digested with trypsin, the resulting peptides were separated by reverse phase HPLC, and their amino acid content was determined (21).

Sulfate flux measurement and DIDS titration. The transmembrane self-exchange flux of sulfate was studied in normal and spherocytic cells as previously described (22). Efflux measurements were performed at $37^{\circ} \mathrm{C}$, at four different values of $\mathrm{pH}(6.4,6.7,6.9$, and 7.1) in Hepes-buffered medium containing $50 \mathrm{mM} \mathrm{K}_{2}^{35} \mathrm{SO}_{4}$. Diisothiocyano-dihydrostilbene-disulfonate (DIDS) titration of ${ }^{35} \mathrm{~S}$ sulfate influx in normal and spherocytic cells was performed as described (23). Influx was measured after $10 \mathrm{~min}$ at $30^{\circ} \mathrm{C}$ in the presence of increasing concentrations of DIDS. This experiment gives an estimate of the relative number of DIDS-binding band 3 protein sites per cell.

Molecular genetic analyses. DNA polymorphisms were analyzed by Southern blotting or PCR-based assays as described for $\alpha$-spectrin: MspI (24), $\alpha^{\text {LELY }}(25,26)$ and $\alpha$ IIa $(27) ; \beta$-spectrin, HindIII $(28,29)$; ankyrin, NcoI $(30,31)$; protein 4.1, HindIII (32); and band 3, PstI $(33,34)$.

Total RNA was isolated from hemolysates of anticoagulated

Table I. Hematological and Biochemical Data

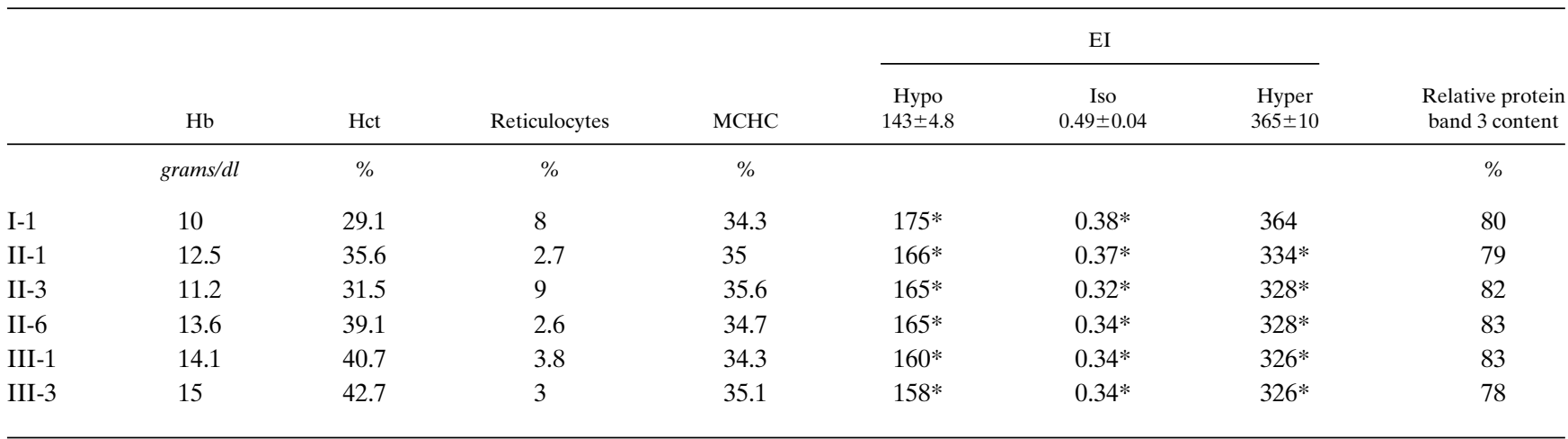

The deformability of the red cells if expressed as EI. When EI is plotted against the osmolality of the suspending medium, the curve obtained shows three remarkable points: the EI in isotonicity (Iso); the minimum index in hypotonicity (Hypo) which corresponds to the maximum volume of the near-spherical cells just before hemolysis; and the index in hypertonicity (Hyper) which corresponds to the osmolality at which EI equals half the normal maximum of the hypertonic arm of the curve. The pathological data are marked with asterisks. Relative band 3 protein content was calculated from the spectrin to band 3 protein ratio. MCHC, mean corpuscular hemoglobin concentration. 


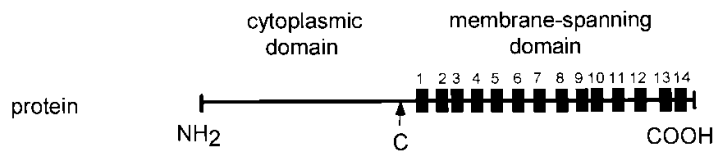

CDNA

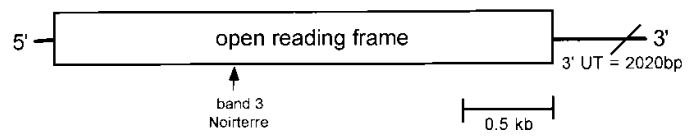

oligomer

primers

$\vec{A} \quad \vec{B}$

$+$

failed to demonstrate the presence of a band 3 protein of abnormal molecular weight (not shown). Quantitation of band 3 content, as measured by the spectrin/band 3 ratio, revealed a deficiency of band 3 between 17 and $22 \%$, in all affected individuals (Table I). In one affected individual, there was normal electrophoretic mobility of band 3 after deglycosylation as well as a normal HPLC profile and amino acid composition of tryptic peptides derived from the cytoplasmic domain of band 3 (not shown). Differential scanning calorimetry (39) also failed to demonstrate any structural abnormality of band 3 in the membranes of three affected family members (data not shown).

Anion transport and DIDS titration. Studies of sulfate selfexchange were carried out in red cells of two $\mathrm{HS}$ patients $\left(\mathrm{II}_{1}\right.$ and $\mathrm{II}_{6}$ ) and demonstrated a $50 \%$ decrease in self-exchange (compared with that in normal RBCs) for each $\mathrm{pH}$ value studied (Fig. 3). In patient $\mathrm{II}_{1}$, the results of DIDS titration of sulfate influx (data not shown) were consistent with a deficiency of band 3 binding sites in the range of a value similar to the quantitative deficiency of band $3(21 \%)$ estimated by densitometric analysis of SDS-PAGE.

Genetic analyses. RFLP analysis of DNA from family members was carried out using DNA markers from various candidate genes. Coinheritance of allelic markers and HS was not observed with the polymorphisms for $\alpha$-spectrin, $\beta$-spectrin, ankyrin, or protein 4.1 (Table III), indicating that there is no close linkage between HS and these genes in this kindred. Both alleles of a band 3 PstI polymorphism were present and segregated in an autosomal dominant fashion in members of this family (Table III). The pattern of inheritance of the band 3 PstI polymorphism shows cosegregation of allele 1 with HS in all members studied. There was no evidence of recombination in this family between this band 3 allele and HS. However, the lod score $(+1.2)$ for linkage between HS and the band 3 gene Sanger et al. (36).

PCR of reverse-transcribed reticulocyte RNA from individuals $\mathrm{II}_{1}, \mathrm{II}_{3}$, and $\mathrm{III}_{1}$ was carried out using primers $\mathrm{A}$ and $\mathrm{H}$ (Table II). These primers amplify a 579-bp fragment that includes all of exon 10 and portions of exons 9 and 11. Amplification products were digested with AlwNI, fractionated by agarose gel electrophoresis, and blotted onto a filter. The blot was probed with an $\sim 1.5 \mathrm{~kb}$ KpnI band 3 cDNA fragment (37) and quantitative analyses of the relative expression of normal and mutant band 3 Noirterre alleles were obtained using a PhosphorImager (Molecular Dynamics, Sunnyvale, CA).

\section{Results}

Hematological studies. The hematological parameters measured in the affected family members are listed in Table I. The diagnosis of HS was established using ektacytometry, as previously described by Clark et al. (38). All of the characteristic features of HS were found in red cells of the patients: a decrease in the ektacytometric index (EI) in isotonic solution, consistent with an intrinsic membrane defect; an increase in the EI in hypotonic solution, consistent with the increased osmotic fragility of the cells; and a decrease in the EI in hypertonic solution, reflecting the presence of red cells with a high mean corpuscular hemoglobin concentration. Mechanical resistance of resealed ghosts was normal in normal and HS individuals.

Biochemical studies. One-dimensional SDS-PAGE of erythrocyte membrane proteins from affected family members was qualitatively normal, including immunoblotting using an antibody specific for the cytoplasmic domain of band 3 which

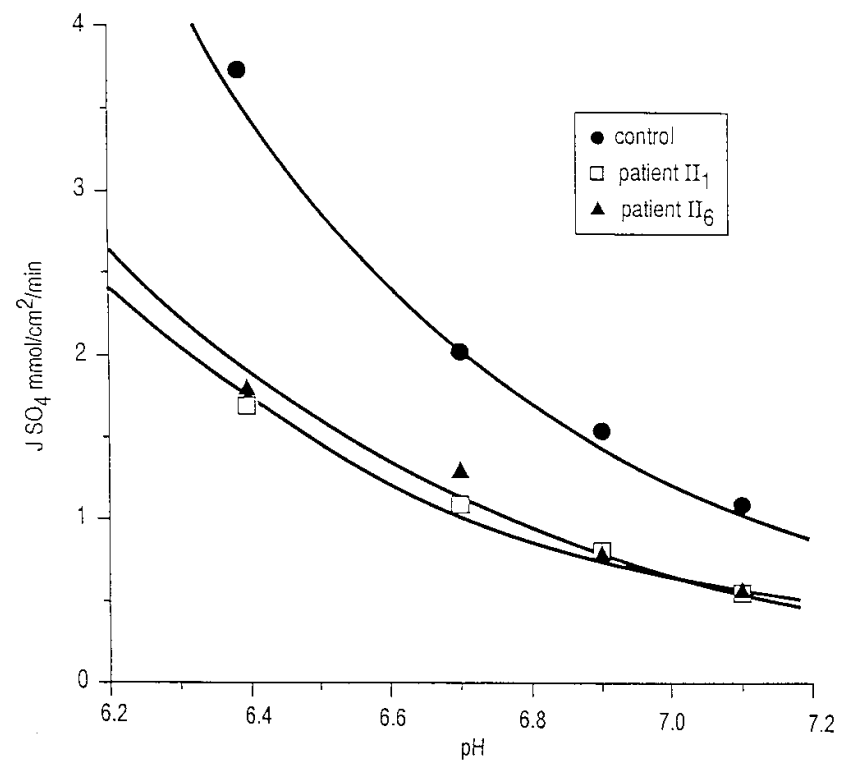

Figure 3. Anion transport in red cells of HS family members. Washed red cells were incubated for $3 \mathrm{~h}$ at $37^{\circ} \mathrm{C}$ in isotonic buffer containing $50 \mathrm{mM} \mathrm{K}_{2}{ }^{35} \mathrm{SO}_{4}$ and $5 \mathrm{mM}$ glucose, at four different $\mathrm{pH}$ values ranging between 6.4 and 7.2 , and the rate of sulfate efflux $\left(\mathrm{JSO}_{4}\right)$ at $37^{\circ} \mathrm{C}$ was measured after transfer of the cells into nonradioactive buffer of the same ionic composition (22). An $\sim 50 \%$ decrease in sulfate selfexchange was observed in red cells of the two $\mathrm{HS}$ family members $\left(\mathrm{II}_{1}\right.$ and $\mathrm{II}_{6}$ ) when compared with that in red cells of a normal individual. 
Table III. Inheritance Pattern of Polymorphisms of Erythrocyte Membrane Protein Genes*

\begin{tabular}{|c|c|c|c|c|c|c|c|}
\hline Polymorphism ${ }^{\ddagger}$ & $\alpha \mathrm{Sp}^{\mathrm{Xbal}}$ & $\alpha \mathrm{Sp}^{\mathrm{LELY}}$ & $\alpha \mathrm{Sp}^{\alpha I I a}$ & $\beta S \mathrm{p}^{\text {HindIII }}$ & $\mathrm{Ank}^{\mathrm{NcoI}}$ & $4.1^{\text {HindIIII }}$ & $\mathrm{B}^{\mathrm{P}_{\text {stI }}}$ \\
\hline \multicolumn{8}{|l|}{ Family member* } \\
\hline I-1 & 1,2 & 2,2 & 2,2 & 1,2 & 1,2 & 1,2 & 1,2 \\
\hline $\mathrm{I}-2$ & 1,1 & 1,2 & 1,2 & 1,2 & 1,2 & 1,1 & 1,1 \\
\hline II-1 & 1,1 & 1,2 & 1,2 & 1,2 & 1,1 & 1,2 & 1,1 \\
\hline II-2 & 1,1 & 2,2 & 1,2 & 2,2 & 2,2 & 2,2 & 1,2 \\
\hline II-3 & 1,1 & 1,2 & 1,2 & 2,2 & 1,2 & 2,2 & 1,1 \\
\hline II-4 & 1,1 & 1,2 & 1,1 & 1,2 & 2,2 & 1,2 & 2,2 \\
\hline II-5 & 1,2 & 1,2 & 1,2 & 1,1 & 1,2 & 1,1 & 1,2 \\
\hline II-6 & 1,1 & 1,2 & 1,2 & 1,1 & 1,1 & 1,1 & 1,1 \\
\hline III-1 & 1,1 & 2,2 & 1,2 & 2,2 & 2,2 & 1,1 & 1,2 \\
\hline III-2 & 1,1 & 1,1 & 1,1 & 1,2 & 1,2 & 1,1 & 1,2 \\
\hline III-3 & 1,1 & 1,2 & 1,2 & 2,2 & 1,2 & 1,1 & 1,2 \\
\hline
\end{tabular}

*The pedigree is shown in Fig. 1. ${ }^{*}$ The polymorphisms analyzed are described in the text.

in this family was not statistically significant. Nevertheless, because other candidate genes had been excluded, it was concluded that a defect in band 3 was the most likely cause of HS in this family, particularly in view of the deficiency in band 3 protein and the abnormality in anion transport.

To elucidate the molecular defect responsible for the abnormality of band 3 in this family, peripheral blood reticulocyte RNA from $\mathrm{HS}$ subject $\mathrm{II}_{3}$ was reverse transcribed into cDNA, and the resulting cDNA was amplified by PCR, subcloned, and subjected to nucleotide sequence analysis. The region of cDNA encoding the $\mathrm{COOH}$-terminal region of the cytoplasmic domain and the entire transmembrane domain of band 3 was analyzed: nucleotides 1032-3008 in the numbering according to Lux et al. (37). Many of the previously reported band 3 mutations associated with typical HS are included in this region (12-15). No consistent nucleotide sequence abnormalities were found in any of the subcloned cDNA fragments analyzed.

Because no mutations were detected in the cDNA, individual band 3 exons from genomic DNA of HS individual III $_{1}$ were amplified, subcloned, and sequenced. A nucleotide substitution was found in exon 10 at codon 330 where $\underline{C A G}$, glutamine, was changed to TAG, a premature termination codon (Fig. 4). This mutation was not present in cDNA subclones analyzed that overlapped this codon.

This mutation abolishes a normally occurring recognition site for the restriction enzyme AlwNI in exon 10, CAGNNNCTG, allowing for rapid, PCR-based detection of the mutation in the genomic DNA of each family member. Amplified DNA products of unaffected individuals were digested by AlwNI into two fragments of 141 and $118 \mathrm{bp}$. AlwNI digestion of the PCR-generated DNA products from the affected HS subjects yielded a digestion-resistant PCR product of $259 \mathrm{bp}$, indicating the presence of the premature stop codon mutation at codon 330 (Fig. 5). This nonsense mutation was only present in the affected HS individuals of the family. The nucleotide sequence of the other band 3 exons ( 2 through 20 ) was normal in at least eight subclones for each exon.

The abolition of a restriction enzyme site allows analysis of the expression of the mutant band 3 Noirterre allele compared with the normal allele at the level of mRNA accumulation (Fig. $6 \mathrm{~A}$ ): cDNA amplification products obtained by RT-PCR and derived from the normal allele should be digested by the restriction endonuclease AlwNI into two fragments of 356 and $223 \mathrm{bp}$, while there should be no digestion of cDNA amplification products derived from the mutant allele (579 bp). RTPCR (25 cycles) of $100 \mathrm{ng}$ reticulocyte RNA from three affected family members and a normal control is shown in Fig. 6 $B$. After digestion with AlwNI, agarose gel electrophoresis, Southern blotting, and autoradiography, there is virtually no visible digestion-resistant cDNA product derived from the mutant band 3 Noirterre allele. The amount of radioactivity

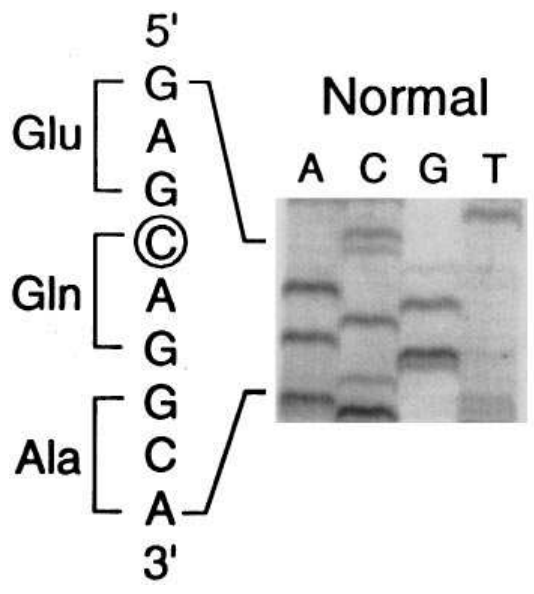

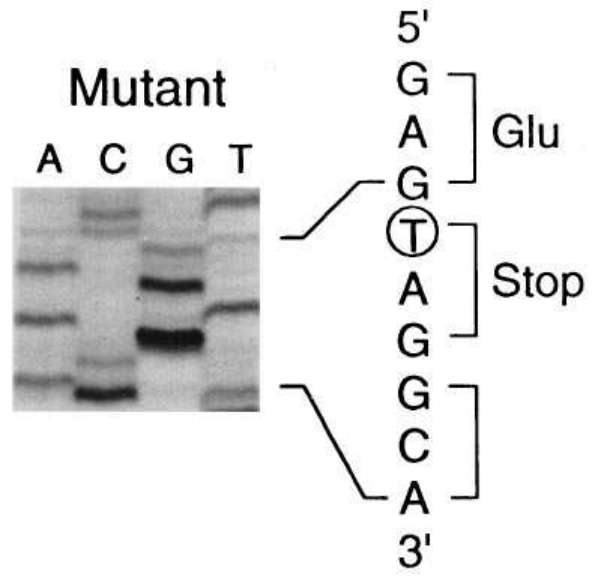

Figure 4. Nucleotide sequence of PCRamplified genomic DNA of individual III $_{1}$ of the kindred. Genomic DNA was amplified using primers flanking exon 10 of the band 3 gene. The amplification products were subcloned and individual clones were sequenced. In approximately half of the subclones, a point mutation was detected, at codon 330 of the band 3 gene, that changes CAG, encoding glutamine, to TAG, a premature termination codon. 


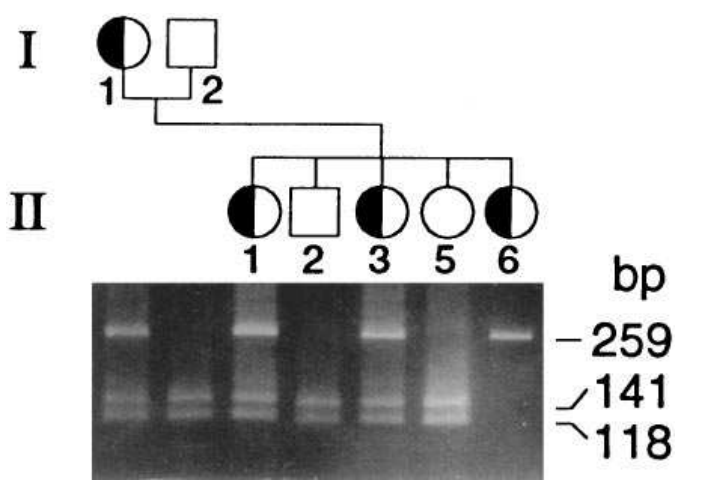

Figure 5. Detection of the band 3 Noirterre mutation in different family members. Genomic DNA corresponding to exon 10 of the band 3 gene was amplified by PCR. Amplification products were digested with the restriction endonuclease AlwN1 and fractionated by electrophoresis in a 4\% agarose gel. Amplification products from unaffected family members are totally digested into fragments of 141 and $118 \mathrm{bp}$. Digested amplification products from affected heterozygous individuals reveal the presence in approximately equimolar amounts of the two normal fragments (141 and $118 \mathrm{bp}$ ), as well as a digestion-resistant fragment of $259 \mathrm{bp}$ due to abolition of the naturally occurring AlwNI site by the band 3 Noirterre mutation in approximately half of the PCR products.

detected by PhosphorImager quantitation for the mutant cDNA (579 bp) relative to that for the normal cDNA (356+ $223 \mathrm{bp})$ is shown in Fig. $6 C$ and indicates that the mutant cDNA is present as only $1-4 \%$ of the total RT-PCR product. Thus, there is very little band 3 Noirterre mRNA detected using this RT-PCR-based assay.

$\mathrm{PCR}$ is an exponential process and small variations in reaction conditions may greatly affect the efficiency of amplification (40). Thus, to validate the results obtained above, similar experiments were performed varying both the amount of total RNA reverse transcribed into PCR template and the number of PCR cycles as described by Foley and Engel (41). Variation in amount of template had a small effect on the amount of mutant cDNA observed which varied from 5 to $14 \%$ (Fig. $7 \mathrm{~A}$ ). Variation in the number of cycles performed demonstrated linearity between 15 and 25 cycles amplification and a range of mutant cDNA from 0 to $9 \%$ (Fig. $7 \mathrm{~B}$ ). Optimized conditions using 100 ng RNA as starting RT-PCR template and varying the number of PCR cycles from 19 to 31 demonstrated little difference in the amount of mutant cDNA product observed, which ranged between 5 and $14 \%$ of the normal cDNA product (Fig. $7 C$ ).

The inheritance of a polymorphism of $\alpha$-spectrin, termed $\alpha$ IIa (27), was studied in this kindred (family Mo in reference 42; see also Table III). This amino acid substitution was initially thought to be frequently associated with, and possibly responsible for, one form of recessively inherited HS $(27,43)$. Because the $\alpha$ IIa allele was inherited in the heterozygous state in both HS and non-HS family members, it was concluded that, in this family, the $\alpha$ IIa polymorphism is not the cause of HS. It is also noteworthy that family member $\mathrm{I}_{1}$ is homozygous for the $\alpha$ IIa allele but is not significantly more severely affected clinically that the other HS members of the family who are heterozygous for the $\alpha$ IIa allele. Thus, in this family, the $\alpha$ IIa allele does not influence the phenotypic expression of HS
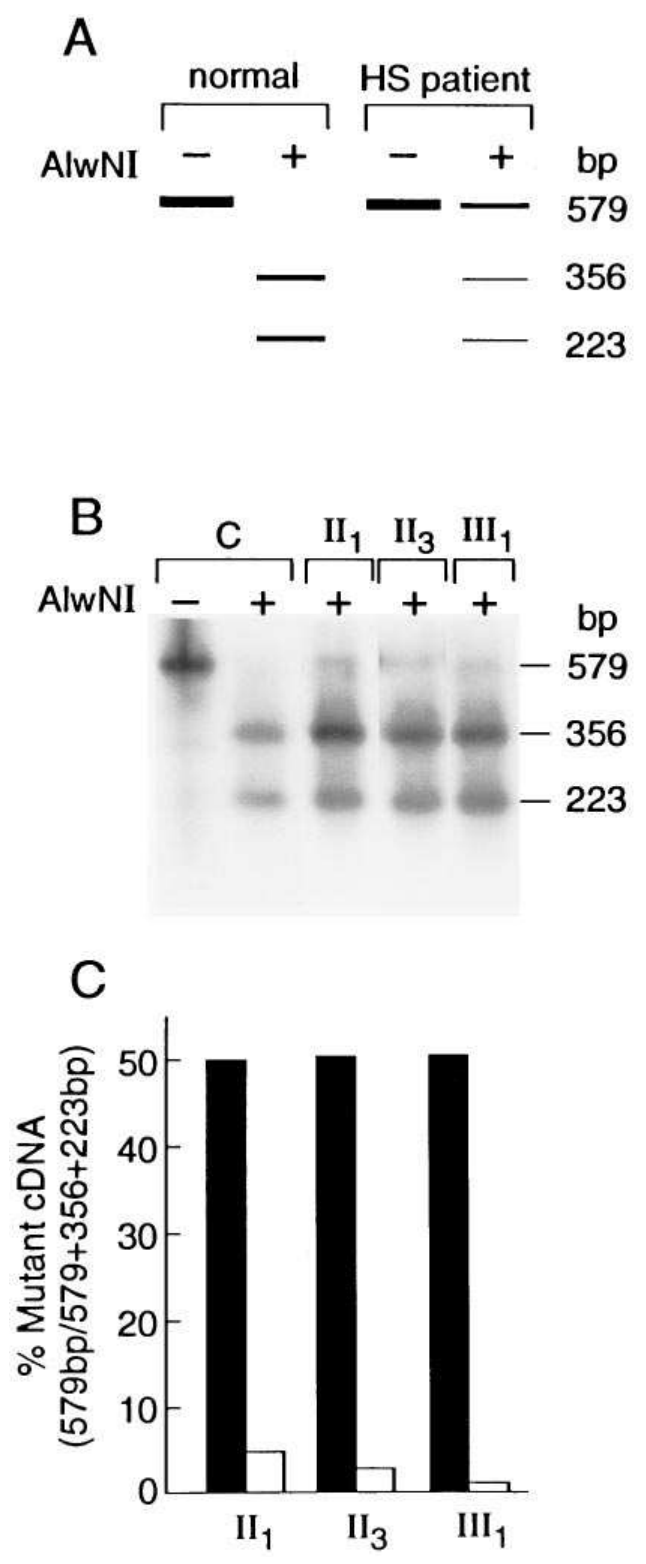

Figure 6. Quantitation of the relative level of mutant band 3 mRNA in reticulocyte RNA by RT-PCR. $(A)$ Diagram of the strategy used to detect the mutant band 3 Noirterre cDNA. After RT-PCR of peripheral blood RNA, normal band 3 cDNA amplification products (579 bp) are totally digested by the restriction endonuclease AlwNI into fragments of 356 and $223 \mathrm{bp}$. The band 3 Noirterre mutation abolishes the AlwNI site in the mutant cDNA product, thus allowing for its detection separately from the normal cDNA product. $(B)$ Autoradiograph of AlwNI-digested RT-PCR products of peripheral blood RNA from three family members and a control individual, followed by agarose gel electrophoresis, blotting, and hybridization to a ${ }^{32} \mathrm{P}$-labeled band $3 \mathrm{cDNA}$ probe. Very little signal is detected at the position of the mutant band 3 Noirterre cDNA product. (C) PhosphorImager quantitation of the autoradiograph shown in $B$. The amount of radioactivity at the position of the mutant PCR product $(579 \mathrm{bp})$ is expressed as a percentage of the total radioactivity at the positions of both normal and mutant cDNA products $(579+356+$ $223 \mathrm{bp}$ ). The relative level (open bars) of mutant band $3 \mathrm{cDNA}$ varies between 1 and $4 \%$ of the total amount of band 3 cDNA products in the three different family members, instead of the expected yield (filled bars) of $50 \%$ if the mutant mRNA were present in reticulocyte RNA at approximately equal levels to that of the normal mRNA. 

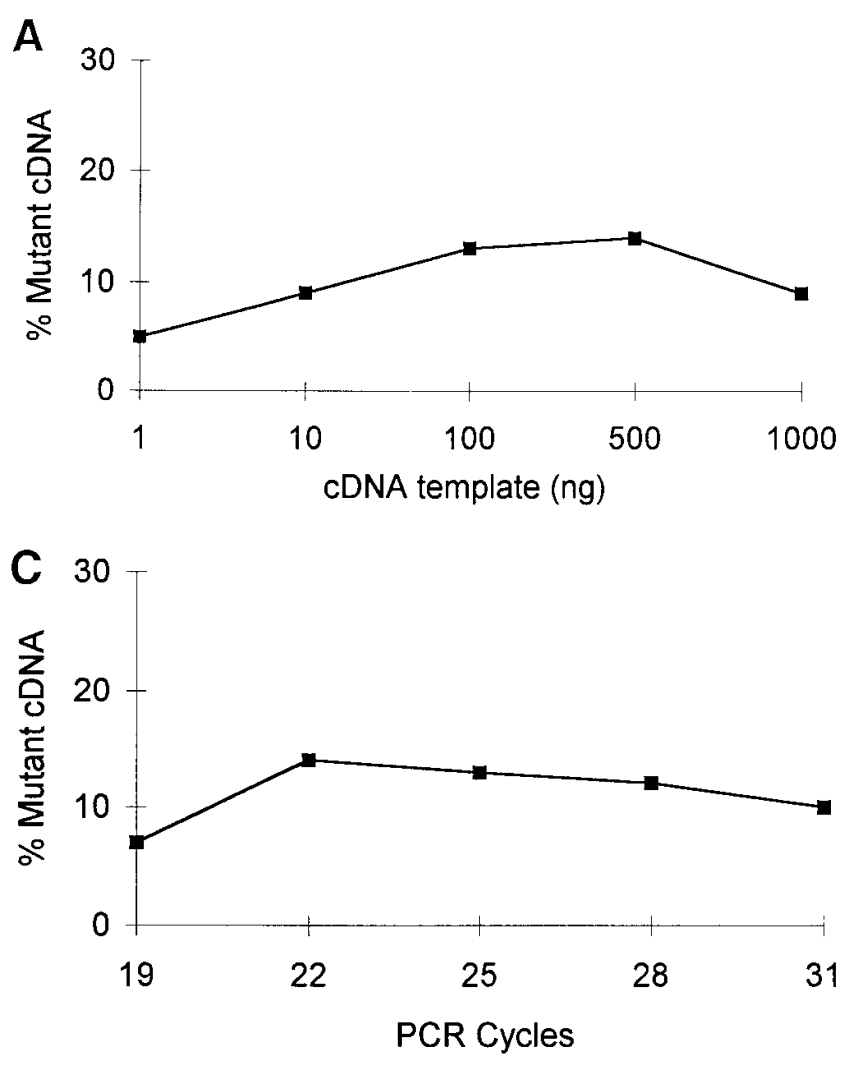

in a gene dosage-dependent manner. Family member $I_{1}$ is also heterozygous for the MspII polymorphism of the $\alpha$ I domain of the $\alpha$-spectrin gene, indicating that she carries the $\alpha$ IIa allele on two different $\alpha$-spectrin gene chromosomal backgrounds.

Recently, another polymorphic allele of $\alpha$-spectrin, $\alpha^{\text {LELY }}$, has been described (25). When the $\alpha^{\text {LELY }}$ allele is coinherited in trans to $\alpha$-spectrin structural variants associated with inherited disorders of the red cell membrane such as hereditary elliptocytosis, a more severe clinical phenotype is observed. We analyzed the inheritance of the $\alpha^{\mathrm{LELY}}$ allele in members of this kindred using a PCR-based assay (26). The $\alpha^{\text {LELY }}$ allele was absent in two of the affected family members $\left(\mathrm{I}_{1}\right.$ and $\left.\mathrm{III}_{1}\right)$, whereas it was present in the heterozygous state in the other four affected family members (Table III). We conclude that the $\alpha^{\text {LELY }}$ allele, like the $\alpha$ II a allele, has no influence on the phenotypic expression of HS in this kindred.

\section{Discussion}

Since the description of a subset of $\beta^{\circ}$-thalassemia patients with extremely low levels of $\beta$-globin mRNA in their reticulocyte RNA (44-48), more than 20 nonsense mutations associated with reduced levels of cytoplasmic mRNA have been described in various human diseases (for review see reference 49). Although many of these mutations are associated with dramatic reductions in steady state levels of mRNA, the degree of reduction can be variable. In general, the closer a nonsense mutation is to the natural site of translation termination, the lesser the degree of mRNA deficiency (49-52). In fact, a normal level of mRNA may be present when the nonsense mutation occurs in the last or next-to-last exon. The markedly decreased amount of mutant mRNA in the use of band 3 Noir-

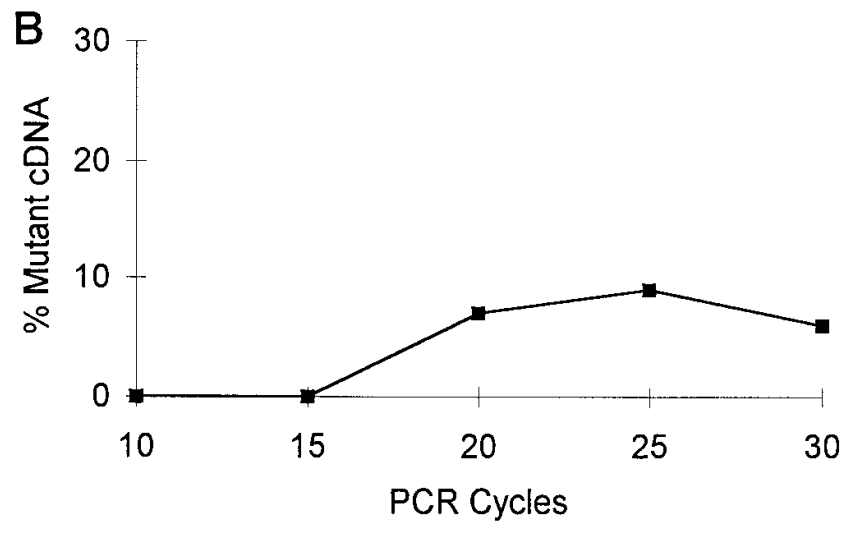

Figure 7. Validation of RT-PCR quantitation of the relative level of mutant band 3 mRNA in reticulocyte RNA. Reticulocyte mRNA RT-PCR experiments were performed as described in Fig. 6. (A) Effect of the amount of RNA template used in RT-PCR on percentage of mutant cDNA. (B) Determination of range of linearity in amplification of mutant cDNA over a wide range of a number of PCR cycles. (C) Optimized conditions using 100 ng RNA as starting RT-PCR template over a range of PCR cycles from 19 to 31. In this range of amplification, only small differences in the percentages of mutant cDNA were observed, with variation from 5 to $14 \%(C)$.

terre is not unexpected, because the mutation occurs in the 10 th of the 20 exons of the band 3 gene.

The mechanism(s) leading to reduced mRNA levels is (are) unknown, as mRNA processing, transport, stability, and/or translation could be involved. Two models attempting to explain this phenomenon have been proposed (52). In the "translational translocation" model, translation begins immediately after the mRNA passes through the nuclear pore, pulling the pre-mRNA through the splicing apparatus and the nuclear membrane. Nonsense mutations stop this process, leading to degradation of the transcript by cellular nucleases. In the "nuclear scanning" model, pre-mRNA is scanned for the presence of premature termination codons before translocation into the cytoplasm. The presence of a premature termination codon would slow or stop the splicing and translocation processes. It has been suggested that a combination of these models is operative in the cell and that neither process is $100 \%$ effective (53), as it appeared to be in this case, explaining the small amounts of transcript that are usually observed with nonsense mutations. Interestingly, recent studies in yeast showed that premature translational termination of mRNA encoding phosphoglycerate kinase triggers decapping of the $5^{\prime}$ end of the mutant mRNA, exposing it to degradation by $5^{\prime} \rightarrow 3^{\prime}$ exonucleases (54).

Nonsense mutations have also been reported to be associated with other alterations in RNA metabolism, including exon skipping (55-57). We did not find any evidence of exon skipping in our RT-PCR-based assay. It has been suggested that nonsense mutations associated with exon skipping may be attributable to decreased complementarity of an exon to U1 snRNA; this phenomenon is usually observed when the mutation occurs near the $5^{\prime}$ donor splice site of the downstream intron (within 12 nucleotides upstream of the invariant GT). The 
band 3 Noirterre mutation occurs 90 nucleotides upstream of the highly conserved GT of the $5^{\prime}$ donor splice site of intron 10 .

Band 3 Noirterre is the first documented example of a nonsense mutation of an erythroid membrane protein gene that is characterized by decreased accumulation of the mutant mRNA. This observation has important implications for mutation screening in the detection of inherited disorders of the red cell membrane. Specifically, if only RT-PCR-based detection methods are used, abnormalities associated with abnormal mRNA processing, such as occurs in the case of band 3 Noirterre, will not be detected. This suggests that alternative methods are required to complement RT-PCR-based screening methods.

Another important observation to be drawn from these studies relates to the pathophysiology of HS. The principal cellular lesion in HS is the loss of membrane surface area relative to cell volume. This loss of surface area has been believed to be due to deficiency of spectrin, the most abundant structural protein of the underlying membrane skeleton, and/or deficiency of ankyrin (1-4, 58-61). However, a subset of typical HS patients, including those with band 3 Noirterre, is associated with normal spectrin and ankyrin content and isolated band 3 deficiency (6-11). The precise role of band 3 deficiency in the pathobiology of HS in these cases is not clear. It has been hypothesized that the erythrocyte membrane is supported by band 3-lipid and band 3-band 3 interactions (2, 3, $6)$. When erythrocyte membranes are deficient in band 3 , there is a larger area between band 3 molecules, resulting in the loss (budding off) of supporting lipids, leading to decreased membrane surface area. Study of the band 3 Noirterre kindred demonstrates that isolated band 3 deficiency, in the absence of a membrane-associated mutant band 3 protein, can lead to the HS phenotype and also to abnormal anion transport. The defect in anion transport in the two HS individuals studied appeared to be more severe $(\sim 50 \%$ decrease in sulfate selfexchange) than the level of protein deficiency determined by SDS-PAGE ( $\sim 20 \%$ deficiency). In the study of the family with band $3^{\text {Prague }}$ (an exon 18 frameshift variant), at least one HS individual demonstrated similar findings, but the average of results from four affected family members indicated quantitatively proportional defects in anion transport and band 3 protein content (12). In the family with band 3 Noirterre, the defect in anion transport must be directly related to the deficiency of band 3 and not to a structurally and functionally abnormal band 3 protein in the membrane, because the predicted truncated mutant protein, lacking all of the transmembrane domain of band 3, would not be capable of becoming membrane-associated, and in fact no mutant protein was detected by various biochemical analyses, including immunoblotting, in RBC membranes of affected family members. We did not study total RBC lysates for the unlikely presence of a cytosolic truncated mutant band 3 protein.

\section{Acknowledgments}

We thank Dr. M. Tanner for communicating sequence information before publication, Dr. P. Low for performing differential scanning calorimetry, Dr. P. Watkins for performing the lod score calculations, and Dr. M. J. Rapp for providing blood samples from the family. We also thank the band 3 family for their helpful participation in this study.

This work was supported in part by grants from the National Institutes of Health.

\section{References}

1. Benz, E. J., Jr. 1994. The erythrocyte membrane and cytoskeleton: structure, function and disorders. In The Molecular Basis of Blood Diseases. 2nd ed. G. Stamatoyannopoulos, A. W. Nienhuis, P. W. Majerus, and H. Varmus, editors. W. B. Saunders Co., Philadelphia. 257-292.

2. Palek, J., and P. Jarolim. 1993. Clinical expression and laboratory detection of red cell membrane protein mutations. Semin. Hematol. 30:249-283.

3. Becker, P. S., and S. E. Lux. 1994. Hereditary spherocytosis and hereditary elliptocytosis. In The Metabolic and Molecular Bases of Inherited Disease. 7th ed. C. R. Scriver, A. L. Beaudet, W. S. Sly, and D. Valle, editors. McGrawHill Inc., New York. 3513-3560.

4. Lux, S., and J. Palek. 1995. Disorders of the red cell membrane. In Blood: Principles and Practice of Hematology. R. I. Handlin, S. E. Lux, and T. P. Stossel, editors. J. B. Lippincott, Philadelphia. 1701-1818.

5. Tanner, M. J. A. 1993. Molecular and cellular biology of the erythrocyte anion exchanger (AE1). Semin. Hematol. 30:34-57.

6. Savvides, P., O. Shalev, K. M. John, and S. E. Lux. 1993. Combined spectrin and ankyrin deficiency is autosomal dominant hereditary spherocytosis. Blood. 82:2953-2960.

7. Jarolim, P., P. Ruff, T. L. Coetzer, J. T. Prchal, S. K. Ballas, M.-C. Poon, V. Brabec, and J. Palek. 1990. A subset of patients with dominantly inherited hereditary spherocytosis has a marked deficiency of the band 3 protein. Blood. 76(Suppl. 1):37a. (Abstr.)

8. Miraglia del Giudice, E., S. Perrotta, L. Pinto, M. D. Cappellini, G. Fiorelli, S. Cutillo, and A. Iolascon. 1992. Hereditary spherocytosis characterized by increased spectrin/band 3 ratio. Br. J. Haematol. 80:133-134.

9. Reinhart, W. H., E. J. Wyss, D. Arnold, and P. Ott. 1994. Hereditary spherocytosis associated with protein band 3 defect in a Swiss kindred. $B r . J$. Haematol. 86:147-155.

10. Miraglia del Giudice, E., A. Iolascon, L. Pinto, B. Nobili, and S. Perrotta. 1994. Erythrocyte membrane protein alterations underlying clinical heterogeneity in hereditary spherocytosis. Br. J. Haematol. 88:52-55.

11. Saad, S. T. O., F. F. Costa, D. L. Vicentim, T. S. I. Salles, and P. H. L. Pranke. 1994. Red cell membrane protein abnormalities in hereditary spherocytosis in Brazil. Br. J. Haematol. 88:295-299.

12. Jarolim, P., H. L. Rubin, S.-C. Liu, M. R. Cho, V. Brabec, L. H. Derick, S. J. Yi, S. T. O. Saad, S. Alper, C. Brugnara, D. Golan, and J. Palek. 1994. Duplication of 10 nucleotides in the erythroid band 3 (AE1) gene in a kindred with hereditary spherocytosis and band 3 protein deficiency (Band $\left.3^{\text {Prague }}\right)$. J. Clin. Invest. 93:121-130.

13. Alloisio, N., P. Texier, A. Forissier, M. L. Ribeiro, L. Murle, M. Rozon, E. Bursaux, P. Maillet, M. L. A. Tanner, G. Tamagnini, and J. Delaunay. 1993. Band 3 Coimbra: a variant associated with dominant hereditary spherocytosis and band 3 deficiency. Blood. 82(Suppl. 1):4a. (Abstr.)

14. Jarolim, P., H. L. Rubin, V. Brabec, L. Chrobak, A. S. Zolotarev, S. L. Alper, C. Brugnara, H. Wichterle, and J. Palek. 1995. Mutations of conserved arginines in the membrane domain of erythroid band 3 lead to a decrease in membrane-associated band 3 and to the phenotype of hereditary spherocytosis. Blood. 85:634-640.

15. Jarolim, P., J. Murray, H. L. Rubin, and J. Palek. 1994. Molecular characterization of hereditary spherocytosis with band 3 deficiency. Blood. 84 (Suppl. 1):362a. (Abstr.)

16. Féo, C., N. Nossal, E. Jones, and M. Bessis. 1982. Une nouvelle technique d'étude de la physiologie des globules rouges: la mesure de leur déformabilité en fonction de l'osmolalité. Résultats obtenus par un ektacytomètre automatisé sur le sang normal et dans différentes anémies hémolytiques. $C R$ Acad. Sci. 195:687-691.

17. Mohandas, N., M. R. Clark, B. P. Health, M. Rossi, L. Wolfe, S. Lux, and S. B. Shohet. 1982. A technique to detect reduced mechanical stability of red cell membranes: relevance to elliptocytic disorders. Blood. 59:768-774.

18. Lecomte, M.-C., M. Garbarz, B. Grandchamp, C. Féo, H. Gautero, I. Devaux, O. Bournier, C. Galand, L. d'Auriol, F. Galibert, et al. 1989. Sp $\alpha^{1 / 78}$. A mutation of the $\alpha$ I spectrin domain in a white kindred with HE and HPP phenotypes. Blood. 74:1126-1133.

19. Fairbanks, G., T. L. Steck, and D. F. H. Wallach. 1971. Electrophoretic analysis of the major polypeptides of the human erythrocyte membrane. Biochemistry. 10:2606-2617.

20. Yannoukakos, D., C. Vasseur, J. P. Piau, H. Wajcman, and E. Bursaux. 1991. Phosphorylation sites in human erythrocyte band 3 protein. Biochim. Biophys. Acta. 1061:253-266.

21. Yannoukakos, D., C. Vasseur, C. Driancourt, Y. Blouquit, J. Delaunay, H. Wajcman, and E. Bursaux. 1991. Human erythrocyte band 3 polymorphism (band 3 Memphis) characterization of the structural modification (Lys $56 \rightarrow$ Glu) by protein chemistry methods. Blood. 78:1117-1120.

22. Bursaux, E., M. Hilly, A. Bluze, and C. Poyart. 1984. Organic phosphates modulate anion self-exchange across the human erythrocyte membrane. Biochim. Biophys. Acta. 777:253-260.

23. Schofield, A. E., D. M. Reardon, and M. J. A. Tanner. 1992. Defective anion transport activity of the abnormal band 3 in hereditary ovalocytic red blood cells. Nature (Lond.). 355:836-837.

24. Hoffman, N., P. Stanislovitis, P. C. Watkins, K. W. Klinger, A. J. Lin- 
nenbach, and B. G. Forget. 1987. Three RFLPs are detected by an alpha spectrin genomic clone. Nucleic Acids Res. 15:4696.

25. Wilmotte, R., J. Marechal, L. Morle, F. Baklouti, N. Philippe, R. Kastally, L. Kotula, J. Delaunay, and N. Alloisio. 1993. Low expression allele $\alpha^{\mathrm{LELY}}$ of red cell spectrin is associated with mutations in exon $40\left(\alpha^{\mathrm{v} / 41}\right.$ polymorphism) and intron 45 and with partial skipping of exon 46. J. Clin. Invest. 91: 2091-2096.

26. Gallagher, P. G., and B. G. Forget. 1994. Spectrin St. Louis and the $\alpha^{\text {LELY }}$ allele. Blood. 81:1686-1687.

27. Marchesi, S., P. Agre, D. W. Speicher, W. T. Tse, and B. G. Forget. 1989. Mutant spectrin $\alpha$ II domain in recessively inherited spherocytosis. Blood. 74(Suppl. 1):182a. (Abstr.)

28. Tse, W. T., M.-C. Lecomte, F. F. Costa, M. Garbarz, C. Feo, P. Boivin, D. Dhermy, and B. G. Forget. 1990. Point mutation in the $\beta$-spectrin gene associated with $\alpha_{1774}$ hereditary elliptocytosis. J. Clin. Invest. 86:909-916.

29. Gallagher, P. G., M.-C. Lecomte, C. Galand, Y.-P. Wang, W. T. Tse, and B. G. Forget. 1994. Location and PCR-based detection of three polymorphisms of the human erythrocyte $\beta$-spectrin gene (SPTB). Br. J. Haematol. 88: 413-414.

30. Costa, F. F., P. Agre, P. C. Watkins, J. C. Winkelmann, T. K. Tang, K. M. John, S. E. Lux, and B. G. Forget. 1990. Linkage of dominant hereditary spherocytosis to the gene for the erythrocyte membrane-skeleton protein ankyrin. N. Engl. J. Med. 323:1046-1050.

31. Gallagher, P. G, W. T. Tse, and B. G. Forget. 1992. Polymerase chain reaction analysis of an NcoI polymorphism of the human erythrocyte ankyrin gene. Blood. 80:1856-1857.

32. Tang, T. K., K.-b. Tam, and S. Chien. 1991. Two RFLPs in the human protein 4.1 gene (EL1). Nucleic Acids Res. 19:6057.

33. Stewart, E. A., R. Kopito, and A. M. Bowcock. 1989. A PstI polymorphism for the human erythrocyte surface protein band 3 (EPB3) demonstrates close linkage of EPB3 to the nerve growth factor receptor. Genomics. 5:633635 .

34. Jenkins, P. B., P. G. Gallagher, and B. G. Forget. 1993. Analysis of a PstI polymorphism of the human erythrocyte band 3 gene (EPB3). Br. J. Haematol. 85:816-818.

35. Schofield, A. E., P. G. Martin, D. Spillett, and M. J. A. Tanner. 1994. The structure of the human red blood cell anion exchanger (EPB3, AE1, band 3) gene. Blood. 84:2000-2012.

36. Sanger, F., S. Nicklen, and A. R. Coulson. 1977. DNA sequencing with chain-terminating inhibitors. Proc. Natl. Acad. Sci. USA. 74:5463-5467.

37. Lux, S. E., K. M. John, R. R. Kopito, and H. F. Lodish. 1989. Cloning and characterization of band 3 , the human erythrocyte anion-exchange protein (AE1). Proc. Natl. Acad. Sci. USA. 86:9089-9093.

38. Clark, M. R., N. Mohandas, and S. B. Shohet. 1983. Osmotic gradient ektacytometry: comprehensive characterization of red cell volume and surface maintenance. Blood. 61:899-910.

39. Moriyama, R., H. Ideguchi, C. R. Lombardo, H. M. Van Dort, and P. S. Low. 1991. Structural and functional characterization of band 3 from Southeast Asian ovalocytes. J. Biol. Chem. 267:25792-25797.

40. Foley, K. P., M. W. Leonard, and J. D. Engel. 1993. Quantitation of RNA using the polymerase chain reaction. Trends Genet. 9:380-385.

41. Foley, K. P., and J. D. Engel. 1992. Individual stage selector element mutations lead to reciprocal changes in $\beta$ - vs. $\epsilon$-globin gene transcription: genetic confirmation of promoter competition during globin gene switching. Genes \& Dev. 6:730-744

42. Boivin, P., C. Galand, I. Devaux, M. C. Lecomte, M. Garbarz, and D. Dhermy. 1993. Spectrin $\alpha$ IIa variant in dominant and non-dominant spherocytosis. Hum. Genet. 92:153-156.
43. Marchesi, S. L. 1991. Mutant cytoskeletal proteins in hemolytic disease. In Ordering the Membrane-Cytoskeleton Trilayer. M. S. Mooseker and J. S. Morrow, editors. Academic Press, San Diego. 155-174.

44. Chang, J. C., and Y. W. Kan. 1979. $\beta^{\circ}$-Thalassemia, a nonsense mutation in man. Proc. Natl. Acad. Sci. USA. 76:2886-2889.

45. Trecartin, R. F., S. A. Liebhaber, J. C. Chang, K. Y. Lee, Y. W. Kan, M. Furbetta, A. Angius, and A. Cao. 1981. $\beta$-Thalassemia in Sardinia is caused by a nonsense mutation. J. Clin. Invest. 68:1012-1017.

46. Takeshita, K., B. G. Forget, A. Scarpa, and E. J. Benz, Jr. 1984. Intranuclear defect in $\beta$-globin mRNA accumulation due to a premature translation termination codon. Blood. 64:13-22.

47. Humphries, R. K., T. J. Ley, N. P. Anagnou, A. W. Baur, and A. W. Nienhuis. 1984. $\beta^{\circ}-39$ thalassemia gene: a premature termination codon causes $\beta$-mRNA deficiency without affecting cytoplasmic $\beta$-mRNA stability. Blood. 64:23-32.

48. Baserga, S. J., and E. J. Benz, Jr. 1988. Nonsense mutations in the human $\beta$-globin gene affect mRNA metabolism. Proc. Natl. Acad. Sci. USA. 85 2056-2060.

49. Cooper, D. N. 1993. Human gene mutations affecting RNA processing and translation. Ann. Med. 25:11-17.

50. Hall, G. W., and S. Thein. 1994. Nonsense codon mutations in the terminal exon of the $\beta$-globin gene are not associated with a reduction in $\beta$-mRNA accumulation: a mechanism for the phenotype of dominant $\beta$-thalassemia. Blood. 83:2031-2037.

51. Cheng, J., M. Fogel-Petrovic, and L. E. Maquat. 1990. Translation to near the distal end of the penultimate exon is required for normal levels of spliced triosephosphate isomerase mRNA. Mol. Cell. Biol. 10:5215-5225.

52. Urlaub, G., P. J. Mitchell, C. J. Cludad, and L. A. Chasin. 1989. Nonsense mutations in the dihydrofolate reductase gene affect RNA processing. Mol. Cell. Biol. 9:2868-2880.

53. McIntosh, I., A. Hamosh, and H. C. Dietz. 1993. Nonsense mutations and diminished mRNA levels. Nat. Genet. 4:219.

54. Muhlrad, D., and R. Parker. 1994. Premature translational termination triggers mRNA decapping. Nature (Lond.). 370:578-581.

55. Dietz, H. C., D. Valle, C. A. Francomano, R. J. Kendzior, Jr., R. E. Pyeritz, and G. R. Cutting. 1993. The skipping of constitutive exons in vivo induced by nonsense mutations. Science (Wash. DC). 259:680-683.

56. Hull, J., S. Shackleton, and A. Harris. 1993. The stop mutation R553X in the CFTR gene results in exon skipping. Genomics. 19:362-364.

57. Belgrader, P., and L. E. Maquat. 1994. Nonsense but not missense mutations can decrease the abundance of nuclear mRNA for the mouse major urinary protein, while both types of mutations can facilitate exon skipping. Mol. Cell. Biol. 14:6326-6336.

58. Agre, P., J. F. Casella, W. H. Zinkham, C. McMillan, and V. Bennett. 1985. Partial deficiency of erythrocyte spectrin in hereditary spherocytosis. $\mathrm{Na}$ ture (Lond.). 314:380-383.

59. Agre, P., A. Asimos, J. F. Casella, and C. McMillan. 1986. Inheritance pattern and clinical response to splenectomy as a reflection of erythrocyte spectrin deficiency in hereditary spherocytosis. N. Engl. J Med. 315:1579-1583.

60. Lux, S. E., W. T. Tse, J. C. Menninger, K. M. John, P. Harris, O. Shalev, R. R. Chilcote, S. L. Marchesi, P. C. Watkins, V. Bennett, et al. 1990. Hereditary spherocytosis associated with deletion of human erythrocyte ankyrin gene on chromosome 8. Nature (Lond.). 345:736-739.

61. Hanspal, M., S. Yoon, H. Yu, J. S. Hanspal, S. Lambert, J. Palek, and J. Prchal. 1991. Molecular basis of spectrin and ankyrin deficiencies in severe hereditary spherocytosis: evidence implicating a primary defect of ankyrin. Blood. 77:165-173. 